\title{
Understanding the links between ecosystem service trade-offs and conflicts in protected areas
}

\author{
Eszter Kovács $^{\text {a,** }}$, Eszter Kelemen ${ }^{a}$, Ágnes Kalóczkai ${ }^{a}$, Katalin Margóczi ${ }^{\text {b }}$, György Pataki ${ }^{\text {c,a }}$, \\ Judit Gébert ${ }^{\mathrm{d}}$, György Málovics ${ }^{\mathrm{d}}$, Bálint Balázs ${ }^{\mathrm{a}}$, Ágnes Roboz ${ }^{\mathrm{c}}$, \\ Eszter Krasznai Kovács ${ }^{\mathrm{e}}$, Barbara Mihók ${ }^{\mathrm{f}}$ \\ a Environmental Social Science Research Group, Department of Environmental Economics, Szent István University, Páter Károly u. 1, Gödölló H-2100, Hungary \\ ${ }^{\mathrm{b}}$ Department of Ecology, University of Szeged, Középfasor 52, H-6726 Szeged, Hungary \\ ${ }^{\mathrm{c}}$ Department of Environmental Economics and Technology, Corvinus University of Budapest, Fövám tér 8, H-1093 Budapest, Hungary \\ ${ }^{\mathrm{d}}$ Faculty of Economics and Business Administration Research Center, University of Szeged, Kálvária sgt. 1, H-6722 Szeged, Hungary \\ e Department of Geography, University of Cambridge, Downing Site, Cambridge CB2 3EN, United Kingdom \\ ${ }^{\mathrm{f}}$ MTA ÖK Lendület Ecosystem Services Research Group, Centre for Ecological Research, Hungarian Academy of Sciences, Alkotmány u. 2-4, H-2163 Vácrátót, \\ Hungary
}

\section{A R T I C L E I N F O}

\section{Article history:}

Received 6 February 2014

Received in revised form

12 September 2014

Accepted 22 September 2014

\section{Keywords:}

Ecosystem services

Trade-offs

Qualitative research

Land use conflicts

Scale

Protected areas

\begin{abstract}
A B S T R A C T
Land use changes induced by nature conservation regulation and management practices, especially in protected areas, often result in trade-offs between ecosystem services (ESs). Exploring trade-offs between ESs and linking them with stakeholders can help reveal the potential losers and winners of land use changes. In this paper, we demonstrate that ES trade-offs do not always go hand in hand with conflicts. The perception of local stakeholders about trade-offs between ESs at three protected sites in the Great Hungarian Plain were assessed through qualitative methods. In all areas significant conservation measures had been introduced since the 1990s resulting in land use changes. Locals (farmers at each site and inhabitants at one site) were the main 'losers' of the land use changes and related ES trade-offs, while there were many winners at different spatial and temporal scales. Conflicts appeared only between locals and the national park directorates, and not between locals and other beneficiaries of the new ESs. Due to scale mismatch, locals might not be in direct contact with other stakeholders, and vice versa, and therefore there is no interface between them for confrontation and negotiation. Integrating scale into the analysis also helps in advising policy instruments to minimise local-level conflicts.
\end{abstract}

(c) 2014 Elsevier B.V. All rights reserved.

\section{Introduction}

Ecosystems provide many goods and services, called ecosystem services (ESs) that contribute to human well-being (MA, 2003, 2005). The ES concept is widely recognised, and its importance is underlined in many policy documents and scientific studies (e.g. Fisher et al., 2009; Gómez-Baggethun et al., 2010; MA, 2003, 2005; TEEB, 2010). Protected areas are designated to conserve natural values and processes, and they enable the provision of many ESs beneficial for local and global communities (Figueroa and Aronson, 2006; Willemen et al., 2013). However, conservation activities in protected areas in many cases lead to land use changes (due to restrictions placed on land use or to rehabilitation activities in degraded ecosystems), which consequently cause trade-offs between ESs (Kari and Korhonen-Kurki, 2013;

\footnotetext{
* Corresponding author. Tel.: + 3628522 000x2261.

E-mail address: kovacs.eszter@kti.szie.hu (E. Kovács).
}

Willemen et al., 2013). Trade-offs often result in changes in the beneficiaries of ESs, which might lead to conflicts between certain stakeholder groups.

Studies focusing on land use conflicts in protected areas (e.g. Harich et al., 2013; Hiedanpää, 2002; Maikhuri et al., 2000; Stoll-Kleemann, 2001a; von Ruschkowski and Mayer, 2011) usually do not link conflicts to ES trade-offs, but they identify stakeholders, their perceptions, needs, motives or the main drivers of the conflicts. Some studies underline that conflicts can arise during the designation or the enlargement of protected areas (or after designation, when management plans are prepared, rehabilitation work starts, protected species are (re)introduced or regulation becomes stricter) (Bagnoli et al., 2008; Hiedanpää, 2002; Stoll-Kleemann, 2001b; West et al., 2006).The main issues vary, and can include relocation of the local population, restrictions on local resource use and economic activities within the park or damage caused by protected species.

On the other hand, there are a number of studies investigating stakeholder perceptions of ESs (e.g. Agbenyega et al., 2009, Lamarque 
et al., 2011, Castro et al., 2011; Petz et al., 2012), but they do not explicitly focus on conflicts or on protected areas. Related to protected areas or conservation goals, few research projects attempt to connect stakeholder preferences of ESs with trade-offs between ESs (Kari and Korhonen-Kurki, 2013; Martín-López et al., 2012). According to these studies knowledge and perceptions about ESs usually differ among stakeholder groups at different scales (Agbenyega et al., 2009; Castro et al. 2011; Kari and Korhonen-Kurki, 2013). Kari and Korhonen-Kurki (2013) show that if regulatory services (e.g. habitat services) are given higher importance for conservation purposes, conflicts might occur between conservation bodies and the local users of provisioning services.

In sum, there are only a few studies that use the ES framework in assessing land use conflicts in protected areas through a qualitative approach (de Groot, 2006; Niedziałkowski et al., 2014). Moreover, in Central and Eastern European (CEE) countries, where substantial changes have occurred in conservation governance since the political transformations of the 1990s (Kluvánková-Oravská, et al., 2009), documented evidence on ES-related conflicts in protected areas is still rare (Niedziałkowski et al., 2014).

Our paper intends to fill this knowledge gap by presenting lessons of qualitative research projects that were conducted in three protected areas in Hungary. The original aim of the research projects was to assess ESs in non-monetary terms, but unintentionally land use conflicts came to the surface at each site. Therefore, for this paper we analysed the data of these research projects especially focusing on ES trade-offs and land use conflicts. We aim to show (1) the links between ES trade-offs and land use conflicts and (2) how the connection between the ES trade-offs, stakeholders and conflicts can assist in advising policy instruments. Our findings also give insight into the regional characteristics of conservation-related land use conflicts in a CEE country.

This paper is organised as follows. In Sections 2 and 3 the explanation of the main concepts and the description of the study areas are given, followed by an introduction to the applied methodology in Section 4. The results and discussion section (Section 5) consists of four main parts. In the first two parts the ES trade-offs and conflicts are discussed: in Section 5.1. the main trade-offs are connected to stakeholders and conflicts, and in Section 5.2 scale and other aspects are included in the analysis. In Section 5.3 different policy instruments are identified, based on the previous analysis, for conflict resolution. In Section 5.4 further methods are presented to enrich and deepen the analysis. Finally, in Section 6 the main lessons are summarised with emphasis on their relevance to conservation policy.

\section{Main concepts and definitions}

\subsection{Ecosystem services}

In our research projects we used the most common definition of ESs as given by the Millennium Ecosystem Assessment (MA): "the benefits that people derive from ecosystems" (MA, 2003, pp. 53). Our typology of ESs was also based on the MA (2003, 2005), and we distinguished provisioning, cultural and regulating services. Supporting services were not included in the final analysis to avoid double counting (Hein et al., 2006; TEEB, 2010) in spite of the fact that at two study sites (Tiszaalpár wetland and Peszéradacs meadows) they were also investigated. For the classification of ESs we used the list of the MA (2005) and Hein et al. (2006) with some modifications.

\subsection{Trade-offs between ESs}

In the current literature on ESs, trade-offs between ESs are often recognised (e.g. Bennett et al., 2009; Rodríguez et al., 2006;
TEEB, 2010). Ecosystems, as complex systems, provide multiple ESs that are interlinked with usually non-linear relations (Bennett et al., 2009; Rodríguez et al., 2006). ESs can co-vary positively or negatively (Ring et al., 2010; TEEB, 2010). In the latter case tradeoffs occur when there is a decrease in the provision or flow of a certain ES as a consequence of an increase in the provision or flow of another ES (Bennett et al., 2009; Rodríguez et al., 2006). In our analysis we applied this definition as a basis for identifying trade-offs between ESs. Trade-offs between ESs can have an effect on different spatial levels from local to global and in different time ranges from the present to a distant future (Ring et al., 2010; Rodríguez et al., 2006, TEEB, 2010). Although ES trade-offs might appear unintentionally, they are frequently the result of certain policy or management decisions. These decisions can affect the quantity and the composition of ESs in a certain ecosystem (Rodríguez et al., 2006). Interventions can have positive (e.g. rehabilitation of degraded areas) or negative effects (e.g. converting biodiversity rich areas into cropland) on biodiversity. It is also emphasised that ES trade-offs can affect different stakeholder groups (Ring et al., 2010; TEEB, 2010).

In our analysis we focused only on the trade-offs between ESs and did not consider other types of trade-offs, e.g. between biodiversity and other goals (e.g. social, economic, political), or between beneficiaries of ESs (see. e.g. McShane et al., 2011, Butler et al., 2013). We concentrated only on those ES trade-offs that were perceived by local stakeholders. In our case ES trade-offs occurred in favour of biodiversity conservation as a consequence of positive changes in nature conservation policy and related management decisions of the national park directorates (NPDs).

\subsection{Stakeholders}

In relation to ESs we used the definition for stakeholders from TEEB: "stakeholders refer to persons, organisations or groups with interest in the way a particular ecosystem services is used, enjoyed and managed" (TEEB, 2010, p. 225). Stakeholders can be grouped in many ways (e.g. primary or secondary, active or passive, according to different spatial and temporal scales, based on economic and social factors, based on their interests and influence) (see e.g. Butler et al., 2013; Grimble and Wellard, 1997; Reed et al., 2009). Swallow et al. (2009) even distinguish beneficiaries, who benefit from ESs, stewards, whose actions affect the flow of ESs and intermediaries, who mediate and shape interactions between the other two groups and the groups and ecosystems.

In our analysis we used the above mentioned definition and we distinguished local, regional and global groups of stakeholders in the present and we also considered the future generation. Local stakeholders were considered as primary stakeholders, especially local farmers, local inhabitants and the NPDs, because they are the most directly affected by any changes in ESs and they have the most direct influence on the flow of ESs as well. They are beneficiaries and stewards as well according to the categorisation of Swallow et al. (2009).

\subsection{Levels of needs related to ESs and ES trade-offs}

ES trade-offs can affect some constituencies of well-being in a positive or negative way (MA, 2003). There are a number of categorisations for the dimensions of human well-being (see e.g. IPBES, 2013; Maes et al., 2013; MA, 2003), which are closely related to different dimensions of human needs and capabilities (see e.g. Maslow, 1943; Max-Neef et al., 1989; Nussbaum, 2006).

In our analysis we used Maslow's hierarchy of needs: physiological, safety, belongingness/love, esteem and self-actualisation (Maslow, 1943) as indicators of changes in well-being of local stakeholder groups. We distinguished two groups of needs: physiological and higher level needs including all other categories 
of Maslow and linked them to ESs, the decrease of which was perceived by some stakeholder groups.

\subsection{Land use conflicts in protected areas}

Conflicts are usually defined as situations, where parties with different goals or interests clash. Conflicts related to ESs often fall into the category of land use conflicts, biodiversity conflicts or conservation conflicts. Land use conflicts can be defined as a conflict where groups of people disagree, have different stakes or interests in how the land should be used (Havel, 1986). In protected areas land use conflicts can also be considered as biodiversity conflicts with focus on differing interests toward some aspects of biodiversity (White et al., 2009) or conservation conflicts, where parties have different opinions about or interests in conservation objectives and activities and where one party is perceived to assert its interest at the expense of another (Redpath et al., 2013). Although these categories are slightly different, in relation to protected areas, they often overlap. They are usually interpreted as a social phenomenon as opposed to human-wildlife conflicts, where wildlife (e.g. certain species) is also considered a stakeholder (Redpath et al., 2013; White et al., 2009). Currently there is no unified or consolidated theoretical basis for researching conservation related conflicts and no unified methods for their analysis, as the focus is usually on case studies (White et al., 2009). In spite of this fact many theoretical approaches can be used for the analysis of conflicts, e.g. theoretical frameworks from sociology (e.g. Dahrendorf, 1958), socialpsychology (e.g. Deutsch, 1949, 1973; Deutsch and Coleman, 2000), or given the complexity of such conflicts more interdisciplinary approaches as well, e.g. political ecology (e.g. Martinez-Alier, 2002) or peace studies (e.g. Galtung, 1965, 1996).

In our analysis we followed the above mentioned definition of land use conflicts and focused on land use conflicts related to trade-offs between ESs in protected areas. The aim was to examine if connecting ES trade-offs with beneficiaries helps us to better understand land use conflicts. Scale, directness of use and the level of needs were used as further aspects in the analysis, but the aim was not to identify other reasons or drivers of conflicts.

\subsection{Policy instruments related to ES trade-offs}

A wide range of policy instruments is available in public policy in general (see e.g. Howlett, 2005) and in biodiversity policy in particular, ranging from regulation through economic incentives to soft policy instruments like information provision (see e.g. OECD, 1999, 2003, 2004). These instruments can be used in relation to ESs as well.

In this paper we advised different policy instruments suited to certain ES trade-offs and to the groups of winners and losers. These instruments included regulation, economic instruments (loans, compensation, payments for ESs (PES), market creation for ESs (MES)), instruments related to information flow (communication, awareness raising, training) and involvement of stakeholders in management (lease agreements, joint planning, adaptive management, involvement of farmers in tourism, educational activities and research).

\section{Study areas and the policy context}

Our research was carried out at three case study sites, located in the eastern part of Hungary, in the Great Hungarian Plain (see Fig. 1). All three sites are part of the Natura 2000 network of the EU and a large proportion of them are also protected under national law.

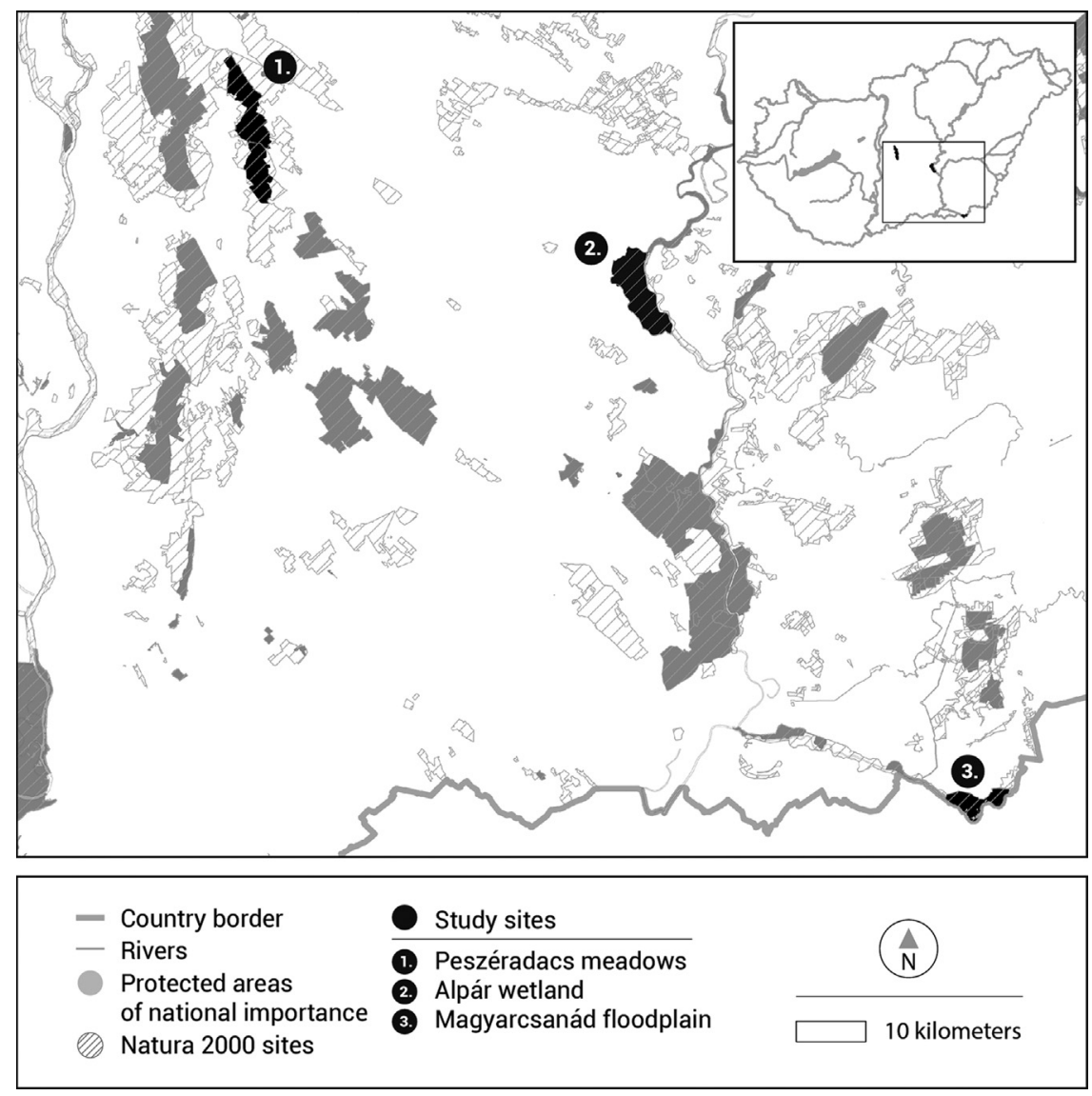

Fig. 1. Map showing the location of the three study sites. 
Table 1

The main characteristics of the applied methods.

\begin{tabular}{|c|c|c|c|c|}
\hline \multicolumn{2}{|c|}{$\begin{array}{l}\text { Main characteristics of the research } \\
\text { projects } \\
\text { Research period }\end{array}$} & $\begin{array}{l}\text { Alpár wetland } \\
\text { November 2007-February } 2009\end{array}$ & $\begin{array}{l}\text { Peszéradacs meadows } \\
\text { May 2010-March } 2012 \\
25 \text { persons: }\end{array}$ & $\begin{array}{l}\text { Magyarcsanád } \\
\text { floodplain } \\
\text { June 2010- } \\
\text { January 2011 } \\
26 \text { persons }\end{array}$ \\
\hline $\begin{array}{l}\text { Semi- } \\
\text { structured } \\
\text { interviews }\end{array}$ & $\begin{array}{l}\text { Number of interviewees } \\
\text { (by stakeholder group) }\end{array}$ & $\begin{array}{l}56 \text { persons } \\
\text { NPD: } 2 \\
\text { Farmers: } 22 \\
\text { Local agricultural agencies: } 2 \\
\text { Local governments: } 3 \\
\text { Regional water management directorate: } 2 \\
\text { Nature conservation NGOs: } 1 \\
\text { Fishermen: } 7 \\
\text { Hunters-foresters: } 6 \\
\text { Local citizens: } 11\end{array}$ & $\begin{array}{l}25 \text { persons: } \\
\text { NPD: } 8 \\
\text { Farmers: } 13 \\
\text { Local agricultural agencies: } 1 \\
\text { Local governments:3 }\end{array}$ & $\begin{array}{l}26 \text { persons } \\
\text { NPD: } 1 \\
\text { Farmers: } 9 \\
\text { Hunters: } 2 \\
\text { Fishermen: } 1 \\
\text { Local } \\
\text { governments: } 3 \\
\text { Local citizens: } \\
10\end{array}$ \\
\hline Focus groups & $\begin{array}{l}\text { Number of focus groups } \\
\text { Main stakeholder groups } \\
\text { involved } \\
\text { Number of participants }\end{array}$ & $\begin{array}{l}3 \text { focus groups } \\
\text { In all three focus groups: land users, mayors, local NGOs, and in } \\
\text { one focus group NPD officials participated as well } \\
4,6 \text { and } 10 \text { persons in Bokros, Lakitelek and Tiszaalpár } \\
\text { respectively }\end{array}$ & $\begin{array}{l}2 \text { focus groups } \\
\text { Focus groups were held for farmers } \\
\text { and for NPD officials separately } \\
17 \text { farmers in the first, } 8 \text { NPD officials } \\
\text { in the second focus group }\end{array}$ & $\begin{array}{l}- \\
- \\
-\end{array}$ \\
\hline
\end{tabular}

NPD: National park directorate.

The first site is the Alpár wetland (approximately 5000 ha) by the river Tisza. During a serious flood in 1998, the area that had previously been used for crop production was turned into a wetland as the dike protecting the fields was destroyed by the regional water management directorate to save the downstream settlements. While the dike was not rebuilt after the flood, the wetland became permanent, preventing farmers from being able to continue their agricultural activities. Part of the site belongs to the Kiskunság National Park, the second oldest national park in Hungary, and the entire area is designated as a Natura 2000 site. It provides habitat for many protected bird and plant species (Bártol, 2008; Kalotás, 2012; Rakonczay, 2001). Four settlements are situated along the wetland: Bokros (now part of Csongrád), Lakitelek, Tiszaalpár and Tiszaug. Lakitelek and Tiszaalpár have a population of less than 5000 each, while Tiszaug and Bokros are much smaller with the number of local inhabitants not reaching 1000 in each settlement (Hungarian Statistical Office, 2013).

The second site is the Peszéradacs meadows (5700 ha), situated on the north-eastern part of the Kiskunság National Park and the Great Hungarian Plain. It is characterised by a diverse and mosaic landscape consisting of patches of marshes, grasslands, pastures and sandy forests. Several rare and endangered plant species can be found here, among them many orchids. The area is very rich in insects and butterflies. Among vertebrates, the meadow viper (Vipera ursinii rakosienis) is the most important reptile species and a wide variety of birds can be seen here (Máté, 2010; Rakonczay, 2001). Extensive livestock grazing is a characteristic of the area, but it has been restricted by nature conservation regulations since the 1990s. Four settlements are located around the meadows: Kunadacs, Kunbaracs, Kunpeszér and Tatárszentgyörgy with a total population of less than 5000 across all four villages (Hungarian Statistical Office, 2013).

The third site is the Magyarcsanád floodplain (approximately 1400 ha) by the River Maros, in the south-eastern part of the Hungarian Great Plain. The area belongs to the Körös-Maros National Park established in 1997, one of the youngest national parks in Hungary. The landscape is characterised by mosaics of grassland, arable land, orchards and forests (Fodor et al., 2011). Farming and forestry activities have been restricted in the area since the 1990s. There are many protected plant and bird species at the study site
(Erdős et al., 2013; Kalotás, 2008; Málovics et al., 2011). Three settlements are located in the vicinity of the floodplain: Apátfalva, Magyarcsanád, and Csanádpalota with a total population of less than 7500 (Hungarian Statistical Office, 2013).

The three sites have common features concerning their land use change history. Before the river control activities of the 19th century, water shaped the landscape at all three sites, nourishing wetlands, grasslands and forests and enabling extensive land use. The controls placed on the Danube, Tisza and Maros Rivers and subsequent drainage considerably changed the water management of the areas and as a consequence wetlands gradually dried and turned into productive agricultural land. During the previous socialist socio-political regime, intensive agricultural production (including forest management of tree plantations) was the dominant land use type at all three sites. Following the political transformation in the 1990s, nature conservation was strengthened in Hungary: a new and progressive nature conservation law was passed in 1996 and new national parks were founded. The national park directorates (NPDs) were able to buy or in some cases appropriate land that was previously managed by cooperatives for conservation purposes (Rakonczay, 2009). NPDs at the study sites used this opportunity to start to manage part of the acquired land themselves, and leased part of it to local land users with restrictions on farming. In order to fulfil conservation goals, the directorates converted croplands into wetlands or grasslands and started the conversion of wood plantations into natural forests (Bártol, 2008; Málovics et al., 2011; Máté, 2010; Molnár, 2003). Overall, a more extensive land use became dominant in the three areas. By the time of Hungary's accession to the EU in 2004, sites of community importance had been designated into the EU's Natura 2000 network, including most of the nationally protected areas (Haraszthy, 2013). In our research area all sites now belong to the Natura 2000 network. After accession, more EU funds became available for rehabilitation work, nature-friendly management on farms and compensation for restrictions (EC, 2007). In the case of the Alpár wetland and Magyarcsanád floodplain, rehabilitation projects have been carried out by national park directorates with EU co-financing to facilitate natural processes and to eradicate invasive species (Bártol, 2008; Gaál et al., 2008). 
In the Alpár wetland an outdoor educational path and an educational centre were established with EU co-funding. Agrienvironmental schemes also became available for land users at all three sites (NHRDP, 2011).

\section{Methodology}

Our findings are based on a secondary analysis of background documents, reports, notes and transcripts of three research projects on qualitative assessment of ESs in order to identify links between ES trade-offs and land use conflicts. The original research projects were carried out between 2007 and 2012 in the three case study areas. The projects in Tiszaalpár wetland and Peszéradacs meadows were co-ordinated by the Szent István University of Gödöllő, while the project in the Magyarcsanád floodplain was coordinated by the University of Szeged. Prior to the field work, desk research was conducted to understand the history of land-use, the sites' natural values, ESs and the socio-economic characteristics of the areas. Qualitative data collection methods such as semistructured interviews (at all sites) and focus groups (at two sites) were applied to identify ESs and trade-offs between ESs perceived as important by different stakeholder groups (see Kelemen et al., 2009; Málovics et al., 2011; Margóczi et al., 2012 for more details about the case studies of Alpár wetland and the Magyarcsanád floodplain). Natural scientists were also consulted for their scientific views on ESs at each study site.

Table 1 provides detailed information on the research methods applied.

The semi-structured interviews (Patton, 2002) focused on how the main stakeholders perceived the ESs of the area, and what changes they saw in the land use patterns and the related ESs. Interviewees were chosen among local stakeholders (key informants and local land users having daily relationship with the natural environment or knowledge about the area) by using purposeful and snowball sampling (Patton, 2002). More interviews were conducted in the Alpár wetland compared to the other two sites due to the larger number of local inhabitants. Interviews lasted from $30 \mathrm{~min}$ to $3 \mathrm{~h}$, with an average duration of an hour and were conducted in pairs, with one of the interviewers asking questions, while the other making detailed notes. Some of the interviews were carried out by graduate students (from the University of Szeged and the Szent István University of Gödölló in the Alpár wetland and Peszéradacs meadows) previously trained by the researchers. In the Alpár wetland 7 interviews, in the Peszéradacs meadows 12 interviews were tape recorded, but in other cases, where the interviewees did not wish researchers to record the discussion, only detailed notes were prepared.

Ecosystem services were not directly mentioned by the researchers during the interviews, since previous experience had shown that locals were not familiar with the term and had difficulties relating to the scientific categories. Questions addressed the personal relationship of the interviewee to the landscape, actual land use practices and their perceived changes, and the valuable elements of the local natural environment.

The focus group method (Barbour, 2007) was applied at two case study sites. In the Alpár wetland area, the aim of the focus groups was to prioritize ESs within the local community and discuss the main trade-offs between ESs. Representatives of different stakeholder groups were invited to the focus group meetings in order to promote sharing and discussion of different views on ESs. The focus groups of Peszéradacs meadows centred on understanding the conflicting situation between local farmers and the NPD. Based on previous experiences in the Alpár wetland, focus group discussions were organised for farmers and NPD officials separately. Clarifying the problems of the farmers was chosen as the main focus of the first discussion and then reflections from the NPD officials on these problems was the focus of the second focus group meeting.

A professional moderator facilitated each meeting, being attentive to give every participant an equal opportunity to take part in the discussions. Focus group meetings lasted between 1.5 and $2 \mathrm{~h}$ and all were tape recorded and literally transcribed for further analysis.

For this paper transcriptions and notes of semi-structured interviews and focus groups were analysed using qualitative content analysis (Stemler, 2001) to unfold the perception of stakeholders on the trade-offs between ESs and related conflicts. An $a$ priori coding agenda (based on the list and categorisation of ESs

Table 2

Consequences of identified ES trade-offs: winners and losers and conflicting parties.

\begin{tabular}{|c|c|c|c|c|c|}
\hline \multirow{2}{*}{$\begin{array}{l}\begin{array}{l}\text { Main aspects } \\
\text { of the } \\
\text { analysis }\end{array} \\
\text { ES trade-offs } \\
\text { ES increased } \\
\quad(\Uparrow) \\
\text { ES } \\
\text { decreased } \\
(\Downarrow)\end{array}$} & \multicolumn{5}{|c|}{ Identified ES trade-offs and their main consequences } \\
\hline & $\begin{array}{l}\text { Provisioning services } \\
(\Uparrow) \text { contra Provisioning } \\
\text { services }(\Downarrow)\end{array}$ & \multicolumn{2}{|c|}{ Regulating services $(\Uparrow)$ contra Provisioning services $(\Downarrow)$} & $\begin{array}{l}\text { Cultural services }(\Uparrow) \\
\text { contra } \\
\text { Provisioning services } \\
(\Downarrow)\end{array}$ & $\begin{array}{l}\text { Regulating services }(\Uparrow) \\
\text { contra } \\
\text { Cultural services }(\Downarrow)\end{array}$ \\
\hline $\begin{array}{l}\text { Main ESs } \\
\text { affected }\end{array}$ & $\begin{array}{l}\text { Fodder }(\Uparrow) \\
\operatorname{Crop}(\Downarrow)\end{array}$ & $\begin{array}{l}\text { Habitats, biodiversity }(\Uparrow) \\
\text { Crop, fodder, meat }(\Downarrow)\end{array}$ & $\begin{array}{l}\text { Flood protection and water } \\
\text { regulation }(\Uparrow) \\
\text { Crop }(\Downarrow)\end{array}$ & $\begin{array}{l}\text { Recreation, education, } \\
\text { research }(\Uparrow) \\
\text { Crop, fodder, meat }(\Downarrow)\end{array}$ & $\begin{array}{l}\text { Habitats, biodiversity }(\Uparrow) \\
\text { Recreation, sense of place } \\
(\Downarrow)\end{array}$ \\
\hline $\begin{array}{l}\text { Winners and } \\
\text { losers }\end{array}$ & $\begin{array}{l}\text { Winners: NPDs } \\
\text { Losers: local farmers }\end{array}$ & $\begin{array}{l}\text { Winners: NPDs local, regional } \\
\text { and global communities, future } \\
\text { generations } \\
\text { Losers: local farmers }\end{array}$ & $\begin{array}{l}\text { Winners: regional water } \\
\text { management directorate, } \\
\text { downstream settlements } \\
\text { Losers: local farmers }\end{array}$ & $\begin{array}{l}\text { Winners: NPDs, local } \\
\text { inhabitants, visitors, } \\
\text { students, researchers } \\
\text { Losers: local farmers }\end{array}$ & $\begin{array}{l}\text { Winners: local, regional and } \\
\text { global communities, future } \\
\text { generations } \\
\text { Losers: local inhabitants }\end{array}$ \\
\hline $\begin{array}{l}\text { Conflicting } \\
\text { parties }\end{array}$ & $\begin{array}{l}\text { Local farmers and the } \\
\text { NPDs }\end{array}$ & Local farmers and the NPD & Local farmers and the NPDs & No conflict occurs & $\begin{array}{l}\text { Local inhabitants and the } \\
\text { NPDs }\end{array}$ \\
\hline $\begin{array}{l}\text { Relevant case } \\
\text { studies }\end{array}$ & Alpár & $\begin{array}{l}\text { Alpár, Peszéradacs, } \\
\text { Magyarcsanád }\end{array}$ & Alpár & $\begin{array}{l}\text { Alpár, Peszéradacs, } \\
\text { Magyarcsanád }\end{array}$ & Magyarcsanád \\
\hline
\end{tabular}

Legend: $(\Uparrow)$ : increased $(\Downarrow)$ decreased, NPD: National park directorate. 
derived from scientific literature) was used to identify the main trade-offs and emergent codes were developed to understand the links between ES trade-offs and conflicts.

\section{Results and discussion}

\subsection{Land use change, trade-offs and conflicts}

Due to the changes in conservation regulation and increased conservation activities, land use changed to a large extent in all three areas. Intensive agricultural and forest management disappeared or were reduced considerably, giving room for the rehabilitation of habitats and nature-friendly management. As a result, some ESs appeared or gained more importance, while others were lost or reduced, so trade-offs occurred between services. The land use changes and the resulting trade-offs between ESs had a strong influence on who gained and who lost in each case study area. One could expect that trade-offs led to conflicts between various stakeholders about access to ESs. However, our empirical data showed that conflicts did not always occur when ES trade-offs could be recognised and that stakeholders in conflict were not always those who were the winners and the losers of the land use change.

Table 2 shows the main type of identified trade-offs between ESs and the consequences in terms of changes in beneficiaries and occurrence of conflicts. We included only ESs where changes were highlighted by the local stakeholders.

\subsubsection{Trade-offs between different provisioning services}

The composition of provisioning services changed in the Alpár wetland. Crop was reduced, while fodder increased. Farmers had to stop crop production on the lower parts of the wetland as the area was continuously under water. The NPD bought or appropriated land in and around the wetland, converted the cropland into grassland and started animal grazing on the upper parts, which was not permanently covered by water.

"Corn is no more but a memory today. We could grow very nice corn in earlier times, it was not weedy, it was rich, but you cannot see it any more. (...) The grey cattle have a more stable future. They can still live on here. This is an environmentally conscious management alternative for this area." (Focus1_Alpár)

In this way the NPD was the winner of the changing provisioning services in the Alpár wetland and the farmers were the losers. It created conflicts between affected parties, while the farmers did not appreciate that the NPD started animal grazing, even if it was a tool for ecological restoration and conservation management in the area. They felt that the NPD started to compete with them for land and also for agri-environmental payments.

\subsubsection{Trade-offs between regulatory and provisioning services (1)}

Regulatory services increased at all three sites, especially with the development of habitats and biodiversity. At the same time, some provisioning services were lost or reduced in quantity, e.g. crop in all three areas, fodder and meat from intensive animal grazing in Peszéradacs meadows and Magyarcsanád floodplain. In the Alpár wetland, as it was previously mentioned, most farmers gave up farming due to the evolution of the wetland and the land acquisition of the NPD. In the Peszéradacs meadows and Magyarcsanád floodplain, agricultural activities had been significantly restricted by the NPDs (e.g. restrictions on water retention, harvesting dates or the maximum number of livestock).

New and improved habitats at all sites were beneficial for the NPDs, for local, regional and global communities, and even for future generations. The main losers of the changes were the local farmers at all sites, whose livelihoods were based on the provisioning services (e.g. crop and fodder) previously provided by the landscape.

Conflicts appeared between the NPDs and farmers only. While restrictions on farming considerably affected the life and subsistence of local farmers, they did not appreciate the evolving natural conditions, even though they were also beneficiaries of the improved habitats. Moreover, the functionality of the reconstructed habitats and the positive effects of increasing biodiversity were questioned by farmers many times. When they observed the disappearance of cultivated plots and saw reconstructed habitats in their transitional state, the landscape looked messy to them, especially when weed or invasive species appeared.

"For me the old cultivated land was the real landscape. The current landscape is wild and feral for me. I would like to restore the older state which is not in contradiction with nature conservation and protected species; they used to have their place in the former times as well." (Int_Alpár)

In the Alpár wetland farmers emphasised that even if they were able to sell their land to the NPD, they were not satisfied, as they intended to continue farming.

"People stopped cultivating their land because of the continuous floods for five or six years. Many even sold their land to the National Park, though farming could be really profitable today." (Int_Alpár)

In the Peszéradacs meadows and Magyarcsanád floodplain farmers could continue farming but the restrictions issued by the NPDs significantly reduced their yield.

"In old times we cut the grass between the 10th and 30th of June. The aftergrass grew until autumn (so it could be grazed), but after a late mowing there is no grass for grazing." (Int_Peszéradacs)

Despite the fact that they could apply for agri-environmental payments to cover their losses, consciously decreasing yield was seen by farmers as a waste of agricultural potential (i.e. fertile soil conditions), which could have been exploited by more intensive farming practices.

They accused the NPD for causing them economic losses.

\subsubsection{Trade-offs between regulatory and provisioning services (2)}

Due to the rehabilitation of the wetland area, flood protection and water regulation also improved in the Alpár wetland, but at the same time crop production decreased. Therefore, a trade-off occurred between regulatory services and the provisioning services in this area. Downstream settlements were the main beneficiaries of the improved flood protection, gaining more security, while the the local farmers experienced losses of crops.

Conflicts appeared between local farmers and the NPD in the Alpár wetland, even though destroying the dam, which flooded the area, was initiated by the regional water management directorate and the main beneficiaries were the downstream towns. The interviewed farmers recognised the downstream settlements as potential gainers, however they accused the NPD as being again the predominant 'winner' of the evolving habitat.

"They let the Tisza out here to protect Csongrád and Szeged [two downstream settlements]. When the Tisza is flooding, there is water everywhere, until the horizon. (...) The floodplain became much uglier since it was designated for protection." (Int_Alpár) 


\subsubsection{Trade-offs between cultural and provisioning services}

The more diverse habitats had a positive influence on some cultural services as well, e.g. scientific research increased in all three areas. Environmental education gained more importance in the Alpár wetland and Magyarcsanád floodplain, while tourism and recreational activities increased in the Alpár wetland and Peszéradacs meadows. Therefore, there was a trade-off between these cultural services and the decreased provisioning services. The NPDs, the local inhabitants, visitors, scientists and students were the winners of the changing situation, while the losers were the local farmers. In spite of the trade-off no conflict occurred between the affected parties concerning cultural services. The reason might be that locals saw an opportunity in these cultural services as well as a source of potential income.

"I believe that we should talk about tourism as a future possibility. But to this end we have to restore the natural beauty of the area and we have to improve the infrastructure. Maybe this can be done in ten years, but who knows how much time is needed in these poor times." (focus1_Alpár)

\subsubsection{Trade-offs between regulatory and cultural services}

In the Magyarcsanád floodplain trade-off occurred between regulatory services (habitat provision) and some cultural services (recreation and sense of place), as the access to some of the previously visited riverbank sites were restricted. Regulating services were appreciated by the NPD, the local, regional and global communities, while the losers of the lost cultural services were the local inhabitants. Even if there were a larger group of winners, and local inhabitants were winners as well, conflicts occurred only between local inhabitants and the NPD. In the interviews local inhabitants expressed their negative feelings about the situation.

"They have bought the road as well and because of the afforestation it is impossible to enter the area. Planting native trees is a good thing but now it is impossible to enter the forest. And the river bank would be so beautiful if there was access to it and an educational path. It is forbidden to fish too. This doesn't support hiking and discovering nature, which is bad, although I don't want to defend anglers because they leave a lot of rubbish behind. This 'Do not step on the grass!' strategy is a bad tactic." (Int_Magyarcsanád)

\subsection{Including scale and other aspects related to the use of ESs in the analysis}

Our investigations showed that mainly locals (farmers in all areas and local residents in the Magyarcsanád floodplain) experienced losses, while groups from local to global scales benefited from the ES-trade-offs. The following table lists the most important ESs identified, the main beneficiaries and some important aspects related to the ESs.

Table 3 helps us in explaining why conflicts occurred only between the NPDs (as winners) and the local resource users (as losers), even though there were other winners of the ES trade-offs. Farmers in all areas were affected by the loss of provisioning services directly used and connected to physiological needs, plus the loss was realised in a short period of time after the changes occurred. Residents in the Magyarcsanád floodplain suffered from the loss of some cultural services. Although these ESs were partly indirectly used and served higher levels of needs (e.g. affection and sense of belonging) they were part of the everyday life of locals before and the loss was experienced shortly after the changes occurred. Even if locals (farmers at all sites and residents in the Magyarcsanád floodplain) might have appreciated some of the new regulating or cultural services as well, these services satisfied higher level needs (e.g. safety and protection, affection and sense of belonging, esteem and self identity), had a longer time range to be realised and were used partly indirectly.

Changes in the land use occurred for nature conservation purposes due to changing nature conservation regulation and the management activities of NPDs in all areas. NPDs played an active role in these changes and they were also one of the winners of ES trade-offs. NPDs are local actors with whom the other local land users (farmers and residents) have direct contact. They have the power to induce land use changes, they have an active presence in the field through their rangers and they are able to control and monitor the activities of other land users. Moreover, while NPDs work for the conservation of a common good, their value orientation is different from the locals, and they many times represent other stakeholder groups at larger spatial scales and future generations. Even if local land users realized the other beneficiaries of the changes (e.g. downstream settlements or visitors and researchers) they did not have direct relations with the other stakeholder groups at larger scales. This scale mismatch might explain why local residents did not consider these other groups as conflicting parties and why they clashed only with NPDs.

\subsection{Using the ES-trade-off-beneficiary-conflict analysis to advice policy instruments}

Linking ES trade-offs with winners and losers at different scales can help identify a broad range of solutions as shown in Table 4.

When conflicts occur between local land users and the NPDs, the use of conflict resolution methods is beneficial. Techniques are available (see e.g. Bagnoli et al., 2008; Daniels and Walker, 2001; Lewis, 1996; Emerson et al., 2003); but NPDs officials might need training or assistance in using these methods and developing the required skills.

Table 3

Changes in ESs, beneficiaries and some related aspects (utilisation, needs and scale).

\begin{tabular}{|c|c|c|c|c|c|c|}
\hline ES & Changes & Beneficiaries & Utilisation & Level of needs & $\begin{array}{l}\text { Spatial scale of the } \\
\text { changes }\end{array}$ & $\begin{array}{l}\text { Temporal scale of the } \\
\text { changes }\end{array}$ \\
\hline Crop & $\Downarrow$ & Farmers & Direct & Physiological & Local & Short term \\
\hline Fodder & $\Uparrow$ & NPD & Direct & Higher levels & Local & Short term \\
\hline Habitat & $\Uparrow$ & NPD, citizens & Indirect & Higher levels & Local to global & Long term \\
\hline Flood protection & $\Uparrow$ & Downstream settlements & Direct & $\begin{array}{l}\text { higher levels } \\
\text { (Safety) }\end{array}$ & Regional & Short to long term \\
\hline $\begin{array}{l}\text { Tourism, education, } \\
\text { research }\end{array}$ & $\Uparrow$ & $\begin{array}{l}\text { NPD, visitors, students, researchers, } \\
\text { citizens }\end{array}$ & $\begin{array}{l}\text { Direct and } \\
\text { indirect }\end{array}$ & Higher levels & Local to global & Short to long term \\
\hline $\begin{array}{l}\text { Recreation, sense of } \\
\text { place }\end{array}$ & $\Downarrow$ & Citizens & $\begin{array}{l}\text { Direct and } \\
\text { indirect }\end{array}$ & Higher levels & Local & Short term \\
\hline
\end{tabular}

Legend: $(\Uparrow)$ increased $(\Downarrow)$ decreased.

* levels of needs are based on the category of Maslow (1943): physiological, safety, belongingness and love, esteem and self-actualisation. 
Table 4

Potential policy instruments related to winners and losers of ES-trade-offs.

\begin{tabular}{|c|c|c|c|}
\hline $\begin{array}{l}\text { ES trade-offs increased ES-decreased } \\
\text { ES }\end{array}$ & Winners-losers & $\begin{array}{l}\text { Need for conflict } \\
\text { resolution } \\
\text { techniques }\end{array}$ & Potential policy instruments (used by NPDs or national policy makers) \\
\hline $\begin{array}{l}\text { Provisioning (fodder)-provisioning } \\
\text { (crop) }\end{array}$ & NPD-farmers & Yes & Communication, lease agreements, training, favourable loans \\
\hline $\begin{array}{l}\text { regulating (habitat)-provisioning (crop, } \\
\text { fodder, meat) }\end{array}$ & NPD-farmers & Yes & $\begin{array}{l}\text { Communication, site specific regulation, assistance in applying for } \\
\text { compensation or PES schemes, assisting in MES schemes, joint planning, } \\
\text { adaptive management }\end{array}$ \\
\hline $\begin{array}{l}\text { regulating (habitat)-cultural (recreation, } \\
\text { sense of place) }\end{array}$ & NPD-local inhabitants & Yes & Communication, joint planning \\
\hline $\begin{array}{l}\text { regulating (habitat)-provisioning (crop, } \\
\text { fodder, meat) }\end{array}$ & $\begin{array}{l}\text { Local to global } \\
\text { communities- } \\
\text { farmers }\end{array}$ & No & Awareness raising, part of taxes allocated to compensation for losses, PES \\
\hline $\begin{array}{l}\text { regulating (flood protection)- } \\
\text { provisioning (crop) }\end{array}$ & $\begin{array}{l}\text { Downstream } \\
\text { settlements-farmers }\end{array}$ & No & PES between winners and losers \\
\hline $\begin{array}{l}\text { cultural (recreation, tourism, education, } \\
\text { research)-provisioning (crop, fodder, } \\
\text { meat) }\end{array}$ & $\begin{array}{l}\text { NPD, visitors, } \\
\text { researchers, } \\
\text { students-farmers }\end{array}$ & No & $\begin{array}{l}\text { MES related to cultural services, involvement of farmers in tourism educational } \\
\text { activities and research }\end{array}$ \\
\hline
\end{tabular}

PES: Payment for ecosystem services, MES: Market for ecosystem services.

In addition, communication with the conflicting parties about the goals and plans of the NPD and the reasons behind management decisions is essential. Our study showed that local land users are usually not fully aware of the goals of the NPDs, such as the rationales behind their activities and the desired or expected results. Therefore it is advisable for NPDs to put more emphasis on information and knowledge sharing and to intensify personal contacts with local people. An active dialogue with local land users can also make conservation activities more effective, especially if locals take part in management activities (Daily et al., 2009; Knight et al., 2006). Through mutual information sharing, conservation experts can learn about local ecological knowledge and experience, while locals might understand the reasons for restrictions and required management much better. With more information on the perceptions of the land users, payments schemes for ESs can be better designed as well (Muradian et al., 2010; Petheram and Campbell, 2010).

If the NPDs and local farmers compete for the use of provisioning services, NPDs can think of involving the farmers in nature management (e.g. in extensive cattle grazing) through leasing agreements, instead of managing the area on its own. However, the required change in land management (e.g. shift from crop production to animal grazing) might be difficult for the farmers and require more training and also financial assistance for the start up (e.g. favourable loans).

In cases where the improvement of habitats is achieved at the expense of losing provisioning services, NPDs can use a wide range of instruments to alleviate the conflict situation and assist farmers. If the NPD has the capacity and authority, it can start to adjust the conservation rules more to the local circumstances in order to better balance the economic and conservation outputs. Assisting the farmers to enrol in compensation or publicly financed payment for ecosystem services (PES) schemes can also be useful. Promoting products based on nature-friendly farming, introducing local brands and helping the evolution of markets for these products may also be ways towards alleviating the difficulties brought about by change. PES and MES (market for ecosystem services) are also advised in the scientific literature (Engel et al., 2008; TEEB, 2011) and guides are available (see e.g. Banerjee et al., 2013; Forest Trends et al., 2008; Smith et al., 2013). In the long run a more intensive collaboration in planning and management and taking steps toward adaptive management is also favourable (see e.g. Allen et al., 2010; Armitage et al., 2007; Borrini-Feyerabend et al., 2004; Holling, 1978), although it requires a robust change in the operation of NPDs.
When the provision of habitat (regulatory service) can be achieved only with restrictions on the access to some cultural services important to local inhabitants, NPDs can involve the local residents in planning the management of the area to find a balance between restricted and freely accessible areas.

When habitat services increase and provisioning services decrease, then communities at larger scales are winners as well. They can be involved in financing the flow of habitat services by contributing to compensation or PES schemes. It is usually done by allocating part of the taxes to finance these schemes. Communication and awareness- raising are especially important in this case, so citizens can gain knowledge about the availability and values of habitats.

When downstream settlements are winning from the increased level of flood protection services, theoretically there is an opportunity to design a PES scheme between these settlements and the farmers, who were affected negatively by the decreased provisioning services. However, institutional arrangements are needed in order to make this solution operational (Greiber and Salzman, 2009).

When cultural services are enjoyed by population at a larger scale, and farmers are the losers of decreasing provisioning services, using products from nature-friendly management in local tourism (e.g. in restaurants, hotels, fairs) can contribute to compensate farmers for their losses. Farmers can also be encouraged to participate in local ecotourism, environmental education activities or even contribute to research, through offering their sites for visits, which can increase their income as well.

\subsection{Further methods to deepen the analysis of ES related conflicts}

Although ES trade-offs can be the main reasons behind land use conflicts in protected areas, further reasons and drivers might exist. Different values, insufficient information, structural problems external to the parties involved and relational problems can also be important factors in a conflict situation (Moore, 2003). In our research the general economic situation of farmers, the relationship of locals with the NPDs in the past, the new regulation of EU accession and available funding, probably also shaped the conflict situations.

Qualitative methods to reveal ES trade-offs and related land use conflicts have their limitations. There might be other trade-offs between ESs besides the ones perceived by the interviewed stakeholders and by those who participated in the focus groups. Ecological, economic and interdisciplinary research can enhance 
the knowledge base on ES trade-offs and the related conflict analysis and resolution. However, some studies underline that interlinkages, synergies and trade-offs between ESs are not yet fully explored, therefore more research is needed in this regard (Bennett et al., 2009; Carpenter et al., 2009; Rodríguez et al., 2006).

Qualitative methods might be combined with the mapping of ES trade-offs. The number of empirical studies aiming to assess ES trade-offs spatially have been increasing recently (e.g. HainesYoung et al., 2012; Raudsepp-Hearne et al., 2010; Ruijs et al., 2013). Participatory mapping of ESs is also gaining importance (e.g. Brown et al., 2012; Klain and Chan, 2012; Raymond et al., 2009). Schägner et al., (2013) show that in many studies mapping is connected even to economic valuation. There have been a few attempts to map ESs services in protected areas and to link them to stakeholders and scales (Butler et al., 2013; Palomo et al. 2013; Willemen et al., 2013). Based on the experience to date mapping can be very useful in the analysis of conflicts related to ES tradeoffs as well (Hauck et al., 2013).

\section{Conclusion}

This paper has explored how useful the ES concept is for identifying the main losses and gains of the land use change in a protected area due to conservation measures. By connecting ES trade-offs to different stakeholders, the winners and losers become apparent, showing a potential for the occurrence of conflicts. For the conflicts to emerge, scale issues become important as only those parties are in direct conflict that interact at the same spatial and time scales (mostly at local scale in the present). It reinforces the findings of other studies that emphasise the importance of scale in the provision and use of ESs and the possibility of scale mismatch (or misfit) in relation to biodiversity policy and governance (Gómez-Baggethun et al. 2013; Hein et al., 2006; Young et al., 2010). Other aspects of the gained and lost ESs, e.g. the level of needs and the directness of the usage might also be important factors in understanding the emergence of the conflict. ESs directly used for subsistence by locals are serving physiological needs, therefore their loss will probably create conflicts between locals and the managers of the protected area. This finding is in line with other studies on ES trade-offs and protected areas (e.g. Kari and Korhonen-Kurki, 2013, Niedziałkowski et al., 2014).

Building on the results of the assessment, policy and other instruments can be advised to handle the scale mismatches and the conflict situations, ranging from conflict resolution to MES schemes. Some studies also emphasise the importance of scale related to the provision of ES and ES trade-offs in designing the policy instruments (De Groot et al., 2010; Hein et al., 2006). In order to become successful, the assistance of the local NPD and governmental conservation bodies are needed in their design and application. For some instruments, for instance direct PES schemes between certain actors, changes in the institutional setting might also be required. NPDs, as the main local conservation actors, have a key role to play in conservation management. However, changes are needed in the operation of NPDs, to be more open for dialogues and cooperation with local stakeholders.

We can also conclude from our analysis that in assessing ESrelated land use conflicts in protected areas a shift might be needed from a pure scientific orientation to more policy-oriented research with closer collaboration with affected stakeholders (Parks and Gowdy, 2013). Indeed, in conservation research, especially related to ESs, the need for more participatory approaches has been recently emphasised (Anton et al., 2010; Cowling et al., 2008; Menzel and Teng, 2009).

\section{Acknowledgements}

The research projects were financed from various sources. In the Tiszaalpár wetland, the Jedlik Ányos Fund (NKFP 3B018_04), in the Peszéradacs meadows, the Hungarian Research Fund (OTKA K78514) under the title "Participatory valuation of agro-ecosystems services" financed the research. In the Magyarcsanád floodplain empirical work was carried out within the project of the Hungary-Romania Cross-Border Co-operation Programme under the title Habitats and ecosystem goods and services evaluation in the Mureş/Maros and Crisul Alb/Koros river valleys co-financed by the European Union (HURO0801/194). Authors of the Szent István University were supported by the Research Centre of Excellence (17586-4/2013/ TUDPOL). Barbara Mihók was supported by the Lendület ("Momentum") Program. We highly appreciate the support of the Environmental Social Science Research Group as well. We would like to thank the graduate students of the University of Szeged and Szent István University of Gödöllô for their participation in conducting interviews. We are grateful for the participants of the interviews and focus groups for sharing their knowledge and opinions and contributing to the success of our research projects. We also thank Balázs Sipos for the preparation of the map. We highly appreciate the comments and suggestions of the two anonymous reviewers and Eeva Primmer as well. Responsibility for all remaining errors and omissions rests with the authors.

\section{References}

Agbenyega, O., Burgess, P.J., Cook, M., Morris, J., 2009. Application of an ecosystem function framework to perceptions of community woodlands. Land Use Policy 26 (3), 551-557.

Allen, C.R., Fontaine, J.J., Pope, K.L., Garmestani, A.S., 2010. Adaptive management for a turbulent future. J. Environ. Manag. 92, 1339-1345.

Anton, C., Young, J., Harrison, P., Musche, M., Bela, G.y., Feld, C.K., Harrington, R., Haslett, J.R., Pataki, G.y., Rounsevell., M.D.A., 2010. Research needs for incorporating the ecosystem service approach into EU biodiversity conservation policy. Biodivers. Conserv. 19 (10), 2979-2994.

Adaptive Co-Management: Collaboration, Learning, and Multi-Level Governance. In: Armitage, D., Berkes, F., Doubleday, N. (Eds.), University of British Columbia Press, Vancouver.

Bagnoli, P., Timo, G., Kovács, E., 2008. People and Biodiversity Policies, Impacts, Issues and Strategies for Policy Action. OECD, Paris.

Banerjee, S., Secchi, S., Fargione, J., Polasky, S., Kraft, S., 2013. How to sell ecosystem services: a guide for designing new markets. Front. Ecol. Environ. 11, 297-304.

Barbour, R., 2007. Doing Focus Groups. Sage, London.

Bártol, R., 2008. Újjáéledő Tisza-ártér, A Kiskunsági Nemzeti Park Igazgatóság KIOP projektjei, Kiskunsági Nemzeti Park Igazgatóság, Kecskemét.

Bennett, E.M., Peterson, G.D., Gordon, L.J., 2009. Understanding relationships among multiple ecosystem services. Ecol. Lett. 12, 1-11.

Borrini-Feyerabend, G., Pimbert, M., Farvar, M.T., Kothari, A., Renard, Y., 2004. Sharing Power: Learning by doing in comanagement of natural resources throughout the world. IIED and IUCN/ CEESP/ CMWG, Cenesta, Teheran.

Brown, G., Montag, J.M., Lyon, K., 2012. Public Participation GIS: A Method for Identifying Ecosystem Services. Soc. Nat. Resour.: Int. J. 25 (7), 633-651.

Butler, J.R.A., Wong, G.Y., Metcalfe, D.J., Honzák, M., Pert, P.L., Rao, N., van Grieken, M.E., Lawson, T., Bruce, C., Kroon, F.J., Brodie, J.E., 2013. An analysis of trade-offs between multiple ecosystem services and stakeholders linked to land use and water quality management in the Great Barrier Reef, Australia. Agriculture, Ecosystems \& Environment 180, 176-191.

Carpenter, S.R., de Fries, R., Dietz, T., Mooney, H.A., Polasky, S., Reid, W.V., Scholes, R. J., 2009. Millennium Ecosystem Assessment: Research Needs. Science 314, 257-258.

Castro, A.J., Martín-López, B., García-LLorente, M., Aguilera, P.A., López, E., Cabello, J., 2011. Social preferences regarding the delivery of ecosystem services in a semiarid Mediterranean region. J. Arid Environ. 75, 1201-1208.

Cowling, R.M., Egoh, B., Knight, A.T., O’Farrell, P.J., Reyers, B., Rouget, M., Roux, D.J., Welz, A., Wilhelm-Rechman, A., 2008. An operational model for mainstreaming ecosystem services for implementation. Proc. Natl. Acad. Sci. USA 105, 9483-9488.

Dahrendorf, R., 1958. Toward a theory of social conflict. J. Confl. Resolut. 2 (2), $170-183$.

Daily, G.C., Polasky, S., Goldstein, J., Kareiva, P.M., Mooney, H.A., Pejchar, L., Ricketts, T.H., Salzman, J., Shallenberger, R., 2009. Ecosystem services in decision making: time to deliver. Front. Ecol. Environ. 7, 21-28.

Daniels, S.T., Walker, G.B., 2001. Working Through Environmental Conflict, The Collaborative Approach. Praeger Publishers, Westport, Conneticut, London. 
de Groot, R., 2006. Function-analysis and valuation as a tool to assess land use conflicts in planning for sustainable, multi-functional landscapes. Landsc. Urban Plan. 75, 175-186.

de Groot, R.S., Alkemade, R., Braat, L., Hein, L., Willemen, L., 2010. Challenges in integrating the concept of ecosystem services and values in landscape planning, management and decision making. Ecol. Complex. 7, 260-272.

Deutsch, M., 1973. The Resolution of Conflict: Constructive and Destructive Processes. Yale University Press, New Haven.

Deutsch, M., 1949. A theory of cooperation and competition. Hum. Relat. 2, 129-152.

Deutsch, M., Coleman, P.T., 2000. The Handbook of Conflict Resolution: Theory and Practice. Jossey-Bass, San Francisco.

EC, 2007. Financing Natura 2000. Guidance Handbook. European Commission DG Environment. Revised version. Available at: 〈http://ec.europa.eu/environment/ nature/natura2000/financing/docs/financing_natura2000_en.pdf) (accessed: August, 2013)

Emerson, K., Nabatchi, T., O'Leary, R., Stephens, J., 2003. The Challenges of Environmental Conflict Resolution. In: O’Leary, R., Bingham, L.B. (Eds.), The Promise and Performance of Environmental Conflict Resolution. Resources for the Future, Washington, DC, pp. 3-26.

Engel, S., Pagiola, S., Wunder, S., 2008. Designing payments for environmental services in theory and practice: an overview of the issues. Ecol. Econ. 65, 663-674.

Erdős, L., Cseh, V., Bátori, Z., 2013. New localities of protected and rare plants in southern Hungary. Tiscia 39, 17-21.

Figueroa, E.B., Aronson, J., 2006. New linkages for protected areas: making them worth conserving and restoring. J. Nat. Conserv. 14, 225-232.

Fisher, B., Turner, R.K., Morling, P., 2009. Defining and classifying ecosystem services for decision making. Ecol. Econ. 68, 643-653.

Fodor, A., Bátori, Z., Cseh, V., Margóczi, K., Körmöczi, L., Erdôs, L., 2011. Inundation area of the Maros near Bökény: land-use history and habitat mapping. In: Körmöczi, L. (Ed.), Ecological and Socio-Economic Relations in the Valleys Of River Körös/Cris and River Maros/Mures. Szeged-Arad, pp. 23-34 (TISCIA monograph series 9.)

Forest Trends, The Katoomba Group, UNEP, 2008. Payments for Ecosystem Services: Getting Started: A Primer. UNON Publishing Services Section. Nairobi.

Gaál, L., Mozsgai, K., Tombácz, E., 2008. A KIOP környezetvédelmi intézkedések céljainak és hatékonyságának vizsgálata összefüggésben a hazai környezetvédelmi fejlesztési irányokkal. ÖKO Zrt. Budapest.

Galtung, J., 1996. Peace by Peaceful Means: Peace and Conflict, Development and Civilization. Sage, London.

Galtung, J., 1965. Institutionalized conflict resolution: a theoretical paradigm. J. Peace Res. 2 (4), 348-397.

Gómez-Baggethun, E., de Groot, R.S., Lomas, P.L., Montes, C., 2010. The history of ecosystem services in economic theory and practice: from early notions to markets and payment schemes. Ecol. Econ. 69, 1209-1218.

Gómez-Baggethun, E., Kelemen, E., Martín-López, B., Palomo, I., Montes, C., 2013. Scale misfit in ecosystem service governance as a source of environmental conflict. Soc. Nat. Resour. 26 (10), 1202-1216.

Greiber, T., Salzman, J., 2009. Enabling institutions. In: Greiber, T. (Ed.), Payments for Ecosystem Services. Legal and Institutional Frameworks, IUCN, Gland, Switzerland, pp. 37-44 (Chapter 5.).

Grimble, R., Wellard, K., 1997. Stakeholder methodologies in natural resource management: a review of principles, context, experiences and opportunities. Agric. Syst. 55 (2), 173-193.

Haines-Young, R., Potschin, M., Kienast, F., 2012. Indicators of ecosystem service potential at European scales: Mapping marginal changes and trade-offs. Ecol. Indic. 21, 39-53.

Haraszthy, L., 2013. Értékőrző gazdálkodás Natura 2000 területeken, Pro Vértes Természetvédelmi Közalapítvány.

Harich, F.K., Treydte, A.C., Sauerborn, J., Owusu, E.H., 2013. People and wildlife: conflicts arising around the Bia Conservation Area in Ghana. J.r Nat. Conserv. 21 (5), 342-349.

Hauck, J., Görg, C., Varjopuro, R., Ratamäki, O., Maes, J., Wittmer, H., Jax, K., 2013. Maps have an air of authority: potential benefits and challenges of ecosystem service maps at different levels of decision making. Ecosyst. Serv. 4, 25-32.

Havel, J.J., 1986. Land use conflicts (Chapter 10). In: Dell, B., Hopkins, A.J.M., Lamont, B.B. (Eds.), Resilience in Mediterranean-type Ecosystems, Tasks for vegetation science, Volume 16. Dr. W. Junk Publishers, Dordrecht, pp. 147-160.

Hein, L., van Koppen, K., de Groot, R.S., van Ierland, E.C., 2006. Spatial scales, stakeholders and the valuation of ecosystem services. Ecol. Econ. 57, 209-228.

Hiedanpää, J., 2002. European-wide conservation versus local well-being: the reception of the Natura 2000 Reserve Network in Karvia, SW-Finland. Landsc. Urban Plan. 61, 113-123.

Holling, C.S., 1978. Adaptive environmental assessment and management. John Wiley and Sons, Chichester.

Howlett, M., 2005. What is a policy instrument? Tools, mixes, and implementation styles. In: Eliadis, P., Hill, M.M., Howlett, M. (Eds.), Designing Government: From Instruments to Governance. McGill-Queen's University Press, Montreal, pp. 31-50.

Hungarian Statistical Office, 2013. Gazetteer of Hungary 1st January. Hungarian Statistical Office, Budapest p. 2013.

IPBES, 2013. Recommended conceptual framework of the Intergovernmental Science-Policy Platform on Biodiversity and Ecosystem Services, United Nations and United Nations Environment Programme, IPBES/2/4. Available: 〈http://www.ipbes.net/images/K1353197-en.pdf〉 (accessed September, 2014).

Kalotás, Zs., 2008. A Körös-Maros Nemzeti Park. A természet szigetei. Alexandra, Pécs.
Kalotás, Zs., 2012. Kiskunsági Nemzeti Park. A víz és szél formálta táj. Alexandra, Pécs.

Kari, S., Korhonen-Kurki, K., 2013. Framing local outcomes of biodiversity conservation through ecosystem services: a case study from Ranomafana, Madagascar Ecosyst. Serv. 3, 32-39.

Kelemen, E., Málovics, G.y., Margóczi, K., 2009. Ökoszisztéma szolgáltatások felmérése során feltárt konfliktusok az Alpári-öblözetben. Termvéd. Közl. 15, 119-133.

Klain, S.C., Chan, K.M.A., 2012. Navigating coastal values: participatory mapping of ecosystem services for spatial planning. Ecol. Econ. 82, 104-113.

Kluvánková-Oravská, T., Chobotová, V., Banaszak, I., Sláviková, L., Trifunovová, S., 2009. From government to governance for biodiversity: the perspective of Central and Eastern European transition countries. Environ. Policy Gov. 19 (3), 186-196.

Knight, A.T., Cowling, R.M., Campbell, B.M., 2006. An operational model for implementing conservation action. Conserv. Biol. 20 (2), 408-419.

Lamarque, P., Tappeiner, U., Turner, C., Steinbacher, M., Bardgett, R.D., Szukics, U., Schermer, M., Lavorel, S., 2011. Stakeholder perceptions of grassland ecosystem services in relation to knowledge on soil fertility and biodiversity. Reg. Environ. Chang. 11, 791-804.

Lewis, C., 1996. Managing Conflicts in Protected Areas. IUCN, Gland, Switzerland and Cambridge.

M.A., 2003. Millennium Ecosystem Assessment, Ecosystems and Human WellBeing: A Framework for Assessment. Island Press, Washington DC.

M.A., 2005. Millennium Ecosystem Assessment, Ecosystems and Human Wellbeing: Synthesis. World Resource Institute, Washington DC.

Maes, J., Teller, A., Erhard, M., Liquete, C., Braat, L., Berry, P., Egoh, B., Puydarrieux, P. Fiorina, C., Santos, F., Paracchini, M.L., Keune, H., Wittmer, H., Hauck, J., Fiala, I., Verburg, P.H., Condé, S., Schägner, J.P., SanMiguel, J., Estreguil, C., Ostermann, O., Barredo, J.I., Pereira, H.M., Stott, A., Laporte, V., Meiner, A., Olah, B., RoyoGelabert, E., Spyropoulou, R., Petersen, J.E., Maguire, C., Zal, N., Achilleos, E., Rubin, A., Ledoux, L., Brown, C., Raes, C., Jacobs, S., Vandewalle, M., Connor, D. Bidoglio, G., 2013. Mapping and Assessment of Ecosystems and their Services An Analytical Framework for Ecosystem Assessments Under Action 5 of the EU Biodiversity Strategy to 2020. Publications Office of the European Union, Luxembourg.

Maikhuri, R.K., Nautiyal, S., Rao, K.S., Chandrasekhar, K., Gavali, R., Saxena, K.G. 2000. Analysis and resolution of protected area-people conflicts in Nanda Devi Biosphere Reserve, India. Environ. Conserv. 27 (1) 43-53.

Málovics, Gy., Margóczi, K., Gébert, J., 2011. Ecosystem services at Magyarcsanád site as perceived by local people (2011). In: Körmöczi, L. (Ed.), Ecological and socio-economic relations in the valleys of river Körös/Cris and river Maros/ Mures. Szeged-Arad, pp. 175-208 (TISCIA monograph series 9).

Margóczi, K., Málovics, G.Y., Gébert, J., Roboz, Á., 2012. Kinek szolgáltat a természet? Termvéd. Közl. 18, 347-358.

Martinez-Alier, J., 2002. The Environmentalism of the Poor: A Study of Ecological Conflicts and Valuation. Edward Elgar, Cheltenham.

Martín-López, B., Iniesta-Arandia, I., García-Llorente, M., Palomo, I., CasadoArzuaga, I., Del Amo, D.G., Gómez-Baggethun, E., Oteros-Rozas, E., PalaciosAgundez, I., Willaarts, B., González, J.A., Santos-Martín, F., Onaindia, M., LópezSantiago, C., Montes, C., 2012. Uncovering ecosystem service bundles through social preferences. PLoS One 7 (6), 1-11.

Maslow, A.H., 1943. A theory of human motivation. Psychol. Rev. 50 (4), 370-396.

Máté, A., 2010. Peszéradacs és a Kurjantó-Balázsi-rétek élővilága, in: Kiskunság Nemzeti Park Igazgatóság. Turjánvidék a Kiskunságban. Boróka füzetek, Kiskunsági Nemzeti Park Igazgatóság, Kecskemét, 71, pp. 9-30.

Max-Neef, M., Elizalde, A., Hopenhayn, M., Herrera, F., Zemelman, H., Jatobá;, J. Weinstein, L., 1989. Human scale development: an option for the future Development Dialogue. J. Int. Dev. Coop. 1, 7-80.

McShane, T.O., Hirsch, P.D., Trung, T.C., Songorwa, A., Kinzig, A., Monteferri, B., Mutekanga, D., van Thang, H., Dammert, J.L., Pulgar-Vidal, M., Welch-Devine, M., Brosius, J.P., Coppolillo, P., O'Connor, S., 2011. Hard choices: making trade-offs between biodiversity conservation and human well-being. Biol. Conserv. 144 (3), 966-972.

Menzel, S., Teng, J., 2009. Ecosystem services as a stakeholder-driven concept for conservation science. Conserv. Biol. 24, 907-909.

Molnár, Zs., (Ed.), 2003. A Kiskunság száraz homoki növényzete. Természetbúvár Alapítvány Kiadó, Kecskemét.

Moore, C.W., 2003. The Mediation Process: Practical Strategies for Resolving Conflict, 3rd Edition Jossez-Bass, A Wiley Imprint, San Francisco.

Muradian, R., Corbera, E. Pascual, U., Kosov, N., May, P.H., 2010. Reconciling theory and practice: An alternative conceptual framework for understanding payments for environmental services. Ecol. Econ. 69, 1202-1208.

NHRDP, 2011. New Hungary Rural Development Programme 2011, Version 7. Available at: 〈http:/www.umvp.eu/sites/default/files/20111122110231.pdf (accessed August, 2013).

Niedziałkowski, K., Blicharska, M., Mikusinski, G., Jedrzejewska, B., 2014. Why is it difficult to enlarge a protected area? Ecosystem services perspective on the conflict around the extension of the Białowieza National Park in Poland. Land Use Policy 38, 314-329.

Nussbaum, M.C.,2006. Poverty and human functioning: capabilities as fundamenta entitlements. In: Grusky, D.B., Kanbur, R. (Eds.), Poverty and Inequality. Stanford University Press, pp. 47-75.

OECD, 1999. Handbook of Incentive Measures for Biodiversity. Design and Implementation. OECD Publications, Paris.

OECD, Q., 2003. Harnessing Markets for Biodiversity: Towards Conservation and Sustainable Use. OECD Publications, Paris.

OECD, 2004. Handbook of Market Creation for Biodiversity, Issues in Implementation. OECD Publications, Paris. 
Palomo, I., Martín-López, B., Potschin, M., Haines-Young, R., Montes, C., 2013. National Parks, buffer zones and surrounding lands: mapping ecosystem service flows. Ecosyst. Serv. 4, 104-116.

Parks, S., Gowdy, J., 2013. What have economists learned about valuing nature? A review essay. Ecosyst. Serv. 3, e1-e10.

Patton, M.Q., 2002. Qualitative Research and Evaluation Methods. Sage, London.

Petheram, L., Campbell, B.M., 2010. Listening to locals on payments for environmental services. J. Environ. Manag. 91 (5), 1139-1149.

Petz, K., Minca, E.L., Werners, S.E., Leemans, R., 2012. Managing the current and future supply of ecosystem services in the Hungarian and Romanian Tisza River Basin. Reg. Environ. Change 12 (4), 689-700.

Rakonczay, Z. (Ed.), 2001. A Kiskunságtól Bácsalmásig, A Kiskunság természeti értékei, Mezőgazda Kiadó, Budapest.

Rakonczay, Z., 2009. A természetvédelem története Magyarországon. Mezőgazda Kiadó, Budapest.

Raudsepp-Hearne, C., Peterson, G.D., Bennett, E.M., 2010. Ecosystem service bundles for analyzing tradeoffs in diverse landscapes. Proc. Natl. Acad. Sci. USA 107 (11), 5242-5247.

Raymond, C.M., Bryan, B.E., MacDonald, D.H., Cast, A., Strathearn, S., Grandgirard, A., Kalivas., T., 2009. Mapping community values for natural capital and ecosystem services. Ecol. Econ. 68 (5), 1301-1315.

Redpath, S.M., Young, J., Evely, A., Adams, W.M., Sutherland, W.J., Whitehouse, A., Amar, A., Lambert, R.A., Linnell, J.D.C., Watt., A., Gutiérrez, R.J., 2013. Understanding and managing conservation conflicts. Trends Ecol. Evol. 28 (2), 100-109.

Reed, M.R., Graves, A., Dandy, N., Posthumus, H., Hubacek, K., Prell, C.h., Quinn, C.H. Stringer, L.C., Morris, J., 2009. Who's in and why? A typology of stakeholder analysis methods for natural resource management. J. Environ. Manag. 90, 1933-1949.

Ring, I., Hansjürgens, B., Elmqvist, T., Wittmer, H., Sukhdev, P., 2010. Challenges in framing the economics of ecosystems and biodiversity: the TEEB initiative. Curr. Opin. Environ.l Sustain. 2 (1-2), 15-26.

Rodríguez, J.P., Beard, T.D., Bennett, E.M., Cumming, G.S., Cork, S.J., Agard, J., Dobson, A.P., Peterson, G.D., 2006. Trade-offs across space, time and ecosystem services. Ecol. Soc. 11, 28.

Ruijs, A., Wossink, A., Kortelainen, M., Schulp, C.J.E., Alkemade, R., 2013. Trade-off analysis of ecosystem services in Eastern Europe. Ecosyst. Serv. 4, 82-94.
Schägner, J.P., Brander, L., Maes, J., Hartje, V., 2013. Mapping ecosystem services' values: current practice and future prospects. Ecosyst. Serv. 4, 33-46.

Smith, S., Rowcroft, P., Everard, M., Couldrick, L., Reed, M., Rogers, H., Quick, T., Eves, C. and White, C., 2013. Payments for Ecosystem Services: A Best Practice Guide. Defra, London.

Stemler, S., 2001. An overview of content analysis. Practical Assessment, Research and Evaluation, 7(17). UHL. 〈http://PAREonline.net/getvn.asp?v=7\&n=17〉 (accessed October, 2013).

Stoll-Kleemann, S., 2001a. Barriers to nature conservation in Germany: a model explaining opposition to protected areas. J. Environ. Psychol. 21, 1-17.

Stoll-Kleemann, S., 2001b. Opposition to the designation of protected areas in Germany. J. Environ. Plan. Manag. 44 (1), 109-128.

Swallow, B.M., Kallesoe, M.F., Iftikhar, U.A., van Noordwijk, M., Bracer, C., Scherr, S.J. Raju, K.V., Poats, S.V., Kumar Duraiappah, A., Ochieng, B.O., Mallee, H., Rumley, R., 2009. Compensation and rewards for environmental services in the developing world: framing pan-tropical analysis and comparison (URL). Ecol. Soc. 14 (2), 26 (accessed: August, 2014)

TEEB, 2010. In: Kumar, Pushpam (Ed.), The Economics of Ecosystems and Biodiversity: Ecological and Economic Foundations. Earthscan, London and Washington.

TEEB, 2011. The Economics of Ecosystems and Biodiversity in Local and Regional Policy and Management. Earthscan, London.

von Ruschkowski, E., Mayer, M., 2011. From conflict to partnership? interactions between protected areas, local communities and operators of tourism enterprises in two german national park regions. J. Tour. Leis Stud. 17 (2), 147-181.

West, P., Igoe, J., Brockington, D., 2006. Parks and peoples: the social impact of protected areas. Annu. Rev. Anthropol. 35, 251-277.

White, R.M., Fischer, A., Marshall, K., Travis, J.M.J., Webb, T.J., di Falco, S., Redpath, S.M. van der Wal, R., 2009. Developing an integrated conceptual framework to understand biodiversity conflicts. Land Use Policy 26, 242-253.

Willemen, L., Drakou, E.G., Dunbar, M.B., Mayaux, P., Egoh, B.N., 2013. Safeguarding ecosystem services and livelihoods: understanding the impact of conservation strategies on benefit flows to society. Ecosyst. Serv. 4, 95-103.

Young, J.C., Marzano, M., White, R.M., McCracken, D.I., Redpath, S.M., Carss, D.N., Quine, C.P., Watt, D., 2010. The emergence of biodiversity conflicts from biodiversity impacts: characteristics and management strategies. Biodivers Conserv. 19, 3973-3990 